\title{
Integrated Design Workflow and a New Tool for Urban Rainwater Management
}

\section{Citation}

Yujiao Chen, Holly W. Samuelson, and Zheming Tong.2016.Integrated Design Workflow and a New Tool for Urban Rainwater Management. Journal of Environmental Management 180:45-51.

\section{Published Version}

10.1016/j.jenvman.2016.04.059

\section{Permanent link}

http://nrs.harvard.edu/urn-3:HUL.InstRepos:27769150

\section{Terms of Use}

This article was downloaded from Harvard University's DASH repository, and is made available under the terms and conditions applicable to Open Access Policy Articles, as set forth at http:// nrs.harvard.edu/urn-3:HUL.InstRepos:dash.current.terms-of-use\#OAP

\section{Share Your Story}

The Harvard community has made this article openly available.

Please share how this access benefits you. Submit a story.

Accessibility 


\title{
INTEGRATED DESIGN WORKFLOW AND A NEW TOOL FOR URBAN RAINWATER MANAGEMENT
}

\author{
Yujiao Chen ${ }^{1,2}$, Holly W. Samuelson ${ }^{2}$, Zheming Tong ${ }^{1,2}$ \\ ${ }^{1}$ Center for Green Buildings and Cities, Graduate School of Design, Harvard University, Cambridge, MA, USA \\ ${ }^{2}$ Harvard Graduate School of Design, Cambridge, MA, USA
}

\begin{abstract}
For stormwater management, Low Impact Development (LID) practices provide more sustainable solutions than traditional piping and storm ponds. However, to be effective, LID practices must be integrated into planning at the beginning of the design process; yet architects and related design professionals making decisions early in the design process are not equipped to consider runoff calculations given their current tools. In response to this dilemma, we have developed an open source stormwater runoff evaluation and management tool: Rainwater+. It is seamlessly integrated into computer-aided design (CAD) software to receive instant estimate on the stormwater runoff volume of architecture and landscape designs. Designers can thereby develop appropriate rainwater management strategies for the project-based on local precipitation data, specific standards, site conditions and economic considerations. We employed Rainwater+ to conduct two case studies illustrating the importance of considering storm water runoff in the early design stage. The first case study showed the importance of integrating rainwater management into design modeling software for the reason that the specific site condition is critical for determining LID practice. The second case study demonstrated the need of visualizing runoff flow direction in assisting the placement of LID practices at proper locations when the terrain is of great complexity.
\end{abstract}

Keywords: Decision-making tool, Rainwater management, Stormwater runoff, LID, Integrated design, Green roof

\section{Introduction}

Rapid urban expansion and the increased impervious surfaces associated with city development have consistently shown to result in degraded aquatic ecosystems (Carter and Jackson, 2007; Hsieh and Davis, 2005; Lee and Bang, 2000; Miltner et al., 2004). The replacement of vegetated areas that provide rainwater interception and storage, often results in an increase in the rate and volume of stormwater runoff (Kim et al., 2003; Mansell, 2003; Whitford et al., 2001). The subsequent urban flooding with increased frequency and severity is exacerbated by the climate change, which causes amplified magnitude of rainfall intensity in some parts of the world (Dore, 2005; Villarreal et al., 2004). The resultant urban flooding causes exceptionally severe damage where massive, rapid urbanization is occurring due to poorly engineered infrastructure (Huong and Pathirana, 2011; Liu, 2009; Wang, 2001). To address this urgent concern, it is crucial for architects and landscape designers to have a greater understanding and modeling capability of stormwater runoff to face the increasing risks in the future. 
In regard to strategies for reduction of high runoff and harvesting of rainwater as an alternative water supply source, the conventional strategy-using piping to partially offset the environmental damage of impervious surfaces - is becoming obsolete because of its limited effect on drainage capacity and pollution control, as well as the high costs and disturbance to local neighborhoods (EPA, 2000). As a result, Low Impact Development (LID) practices have been suggested as a viable solution (Burns et al., 2012; Chang, 2010; Dietz, 2007; Qin et al., 2013). LID practices increase sustainability by using porous pavement, bioretention, green roofs, rainwater harvesting and other strategies that manage rainwater as close to its source as possible. These approaches increase groundwater replenishment, rainwater reuse, and on-site water balance, while mitigating downstream flooding (Pyke et al., 2011).

In the U.S., the rainwater runoff of a development project is calculated by hydrology engineers who are usually engaged during the design development phase or perhaps even later. In addition, for the sizing of conventional runoff management such as retention ponds or drainage pipes, hydrology engineers could conduct the task with little participation by the architectural team. Unfortunately, overlooking the site hydrology in the early design stage can lead to many challenges when incorporating LID strategies. This is because many LID practices must be integrated with other design elements or, to some extent, are parts of the design itself. Architects and landscape designers must be able to develop preliminary on-site stormwater management strategies in harmony with early architectural, structural and landscape design. Addressing the problem later in the process may limit one's options for selection, location or sizing of systems. Moreover, since local regulations, environmental standards such as LEED (USGBC, 2013) and design best practices increasingly mandate rainwater management targets, project teams need to consider runoff issues as an integrated part of the early design to guarantee the fulfillment of their goals. The team should be able to conduct quick compliance checks, and if the design falls short, adjust their strategies accordingly.

To address the issues discussed earlier in the paper, there is a need for developing a stormwater runoff model that provides quantitative visualization and estimation that incorporates site geometries. There are only few models in the market for stormwater runoff calculation that can benefit landscaping design. The most advanced tool is EPA's Storm Water Management Model (SWMM) (Huber et al., 2005). It is a rainfall-runoff simulation model that predicts runoff quantity and quality from primarily urban areas. It is not friendly to landscape designers for the following reasons. First, the model does not support direct import of complex computer-aided design (CAD) geometries. Second, the model simplifies terrain to two dimensions, which does not indicate runoff flow directions. HydroCAD is another application developed by HydroCAD Software Solutions, LLC (Koo, 1989). Its function is limited to water conveyance and pond design (including storage chamber), but this model has no capacity for other runoff management practices such as green roofs, permeable pavement or rainwater harvesting. The model presented in the paper is the first one to our knowledge that offers 1) graphical visualization of buildings 
and landscape; 2) prediction of runoff flow directions; and 3) user-friendly interface for architect and landscape designers.

This paper is organized as follows: We start with a detailed description of our numerical model, Rainwater+. Next, we share two case studies that employed the Rainwater+ softwareto illustrate the importance of considering stormwater runoff in the early design stage. Finally, we provide design recommendations based on the results of our analysis.

\section{Model Description}

Rainwater+ presented in this paper is an intuitive and interactive tool for use in the early design process, which was designed to better serve architects, landscape designers and ultimately the hydrological engineers who work with them. Rainwater+ is an open source model available for download from the website, www.rainwaterplus.com

Rainwater+ is built upon the software platforms Rhinoceros and Grasshopper, developed by Robert McNeel \& Associates. Rhinoceros is one of the fastest-growing, three-dimensional modeling tools for architects and landscape designers. As many designers are already familiar with Rhinoceros, Rainwater+ allows them to consider stormwater runoff based on existing geometries without interrupting their workflow by having to engage a separate tool. The model is developed with Grasshopper, a graphical programming platform integrated with Rhinoceros's 3D modeling tools. Using this platform, Rainwater+ is able to provide instant feedback based on CAD models throughout the entire design process. Rainwater+ is positioned to address rainwater management issues of site less than $1 \mathrm{~km} 2$ - the relatively small and integrated drainage basins in urban built-up regions that are vulnerable to severe urban flood risks (Lee and Heaney 2003, Dietz and Clausen 2008).

\subsection{Model Features}

Rainwater+ can be used for design evaluation, decision-making, compliance checking, and rough cost estimation. It is comprised of four major process components that will be discussed in greater detail: 1) a built-in precipitation database; 2) a terrain analysis tool; 3) a runoff volume calculator; and 4) a library of LID practices and sizing components. The interface integrates directly with the designer's model in Rhinoceros. All components, except the terrain analysis tool, will also function with a two-dimensional drawing as well as a 3D model. 


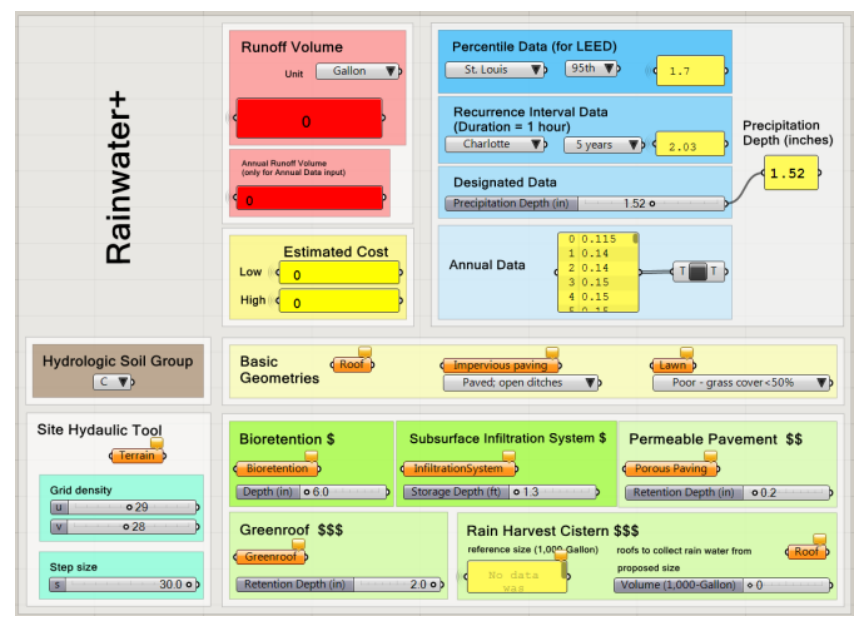

Figure 1 Interface of Rainwater+

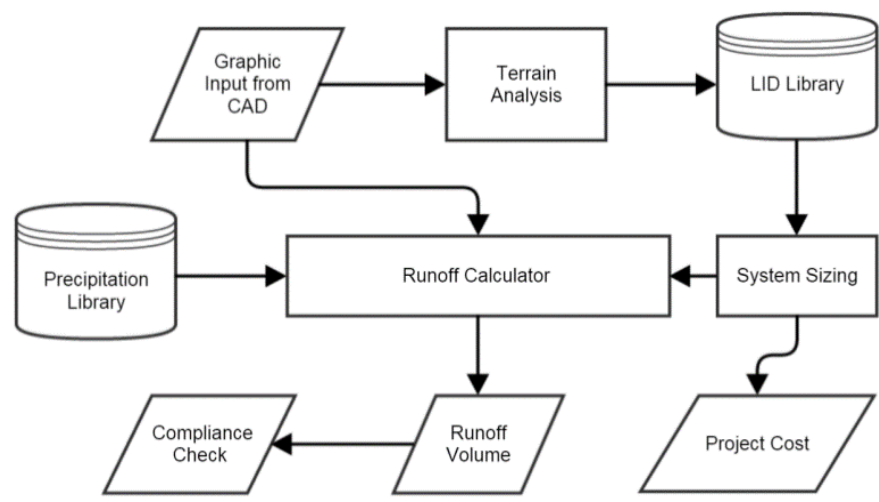

Figure 2 Workflow of Rainwater+

\section{Precipitation Database}

Rainwater+ contains a library of multiple types of precipitation data input. Rainwater+ currently includes a library of percentile data input (85th, 90th and 95th percentile rainfall event data for 16 major cities in the United States), as well as recurrence interval data inputs (once in 1, 2, 5, 10, 25, 50 or 100 year rainfall events for 13 major cities in the United States). The precipitation data are from the National Oceanic and Atmospheric Administration's (NOAA) Precipitation Frequency Data Server (PFDS).

\section{Terrain Analysis Tool}

The terrain analysis function in Rainwater+ interprets a three-dimensional site plan to visualize the site's hydrological flow conditions. This is realized by an iterative algorithm. A grid of nodes is projected onto the terrain surface. For each of the nodes, the algorithm locates the lowest node in elevation at one step size away from the previous node. The node then moves to the new location, and the process repeats. The density of the grid and the step size can be adjusted by the user. This feature allows users to visualize surface flow, which helps designers re-grade the site, 
if necessary, and place runoff mitigation systems, such as bioretention, in the most appropriate locations.

\section{Library of LID Practices and Sizing Components}

Rainwater+ can evaluate the effects of various rainwater management strategies. The current LID library includes bioretention systems, subsurface infiltration systems, permeable pavements, green roofs and rain harvest cisterns. The model first evaluates the runoff volume of the current conditions before LID treatment. In the LID design phase, Rainwater+ helps designers determine the coverage area and storage capacity of the bioretention system or subsurface infiltration system based on site topology and runoff reduction targets. The model is coded to automatically update the runoff volume in real time whenever there are changes in location, size or designed retention depth of the geometry, which provides convenience, particularly in the early design stage.

\subsection{Calculation Method}

In order to calculate runoff depth, the Natural Resource Conservation Service (NRCS) Curve Number method (Cronshey, 1986; Durrans and Dietrich, 2003; USDA, 1985), developed by the U.S. Department of Agriculture (DOA), was selected for Rainwater+ among several available runoff calculating methods. This method was chosen because of its relatively complete database, as well as the fact that it has been widely used for decades (Chung et al., 2010; Tsihrintzis and Hamid, 1997). This method is shown as Equations 1, 2 and 3.

$$
P_{e}=\frac{\left(P-I_{a}\right)^{2}}{\left(P-I_{a}\right)+S}
$$

Where:

$\mathrm{P}_{e}=$ depth of effective precipitation (runoff)

$\mathrm{P}=$ total rainfall depth in storm event

$I_{a}=$ equivalent depth of initial abstractions

$\mathrm{S}=$ maximum possible water retention

Data analyzed by the NRCS indicated that on average, $\mathrm{I}_{\mathrm{a}}=0.2 \mathrm{~S}$, thus the equation above becomes

$$
P_{e}=\frac{(P-0.2 S)^{2}}{P+0.8 S}
$$

The maximum possible retention $\mathrm{S}$ is related to the curve number $(\mathrm{CN})$ :

$$
S=\frac{1000}{C N}-10
$$

Where: $\mathrm{CN}$ = runoff curve number 
The curve number used in Rainwater+ and shown in Table 1 is from Urban Hydrology for Small Watersheds TR-55 by the U.S. DOA (Cronshey et al., 1985). In the Rainwater+ calculation, the curve number is automatically read from the table based on the land cover condition of each surface and user-specified soil type. Detailed land cover conditions are assigned to geometries (individual, group or layer) in the designer's model, which enables Rainwater+ to read geometry data from Rhinoceros.

Table 1: Land cover description and curve number

\begin{tabular}{|c|c|c|c|c|}
\hline \multirow{2}{*}{ Cover description } & \multicolumn{4}{|c|}{$\begin{array}{c}\text { Curve numbers } \\
\text { for hydrologic soil group }\end{array}$} \\
\cline { 2 - 5 } & $\mathrm{A}$ & $\mathrm{B}$ & $\mathrm{C}$ & $\mathrm{D}$ \\
\hline $\begin{array}{c}\text { Lawns } \\
\text { Poor condition (grass cover } \mathbf{5} 50 \%)\end{array}$ & 68 & 79 & 86 & 89 \\
\hline $\begin{array}{c}\text { Lawns } \\
\text { Fair condition (grass cover 50\% to 75\%) }\end{array}$ & 49 & 69 & 79 & 84 \\
\hline $\begin{array}{c}\text { Lawns } \\
\text { Good condition (grass cover }>\mathbf{7 5 \%} \text { ) }\end{array}$ & 39 & 61 & 74 & 80 \\
\hline Roofs & 98 & 98 & 98 & 98 \\
\hline Paved parking lots & 98 & 98 & 98 & 98 \\
\hline Paved (curbs and sewers) & 98 & 98 & 98 & 98 \\
\hline Paved (open ditches) & 83 & 89 & 92 & 93 \\
\hline Gravel & 76 & 85 & 89 & 91 \\
\hline Dirt & 72 & 82 & 87 & 89 \\
\hline Newly graded areas & 77 & 86 & 91 & 94 \\
\hline
\end{tabular}

Soils in the United States have been classified by the NRCS into four hydrologic groups: A, B, C and D, as shown in Table 2. Group A soils have high infiltration rates. These soil types are available for selection by the user in Rainwater+. Hydrologic soil groups for locations in the United States can be found on NRCS's SOILS website (soils.usda.gov).

Table 2 Hydrologic soil group

\begin{tabular}{|c|c|c|}
\hline Type & Infiltration Rate & Texture \\
\hline A & $\begin{array}{c}0.30-0.45 \mathrm{in} / \mathrm{hr} \\
(0.76-1.14 \mathrm{~cm} / \mathrm{hr})\end{array}$ & Sand and gravels \\
\hline B & $\begin{array}{c}0.15-0.30 \mathrm{in} / \mathrm{hr} \\
(0.38-0.76 \mathrm{~cm} / \mathrm{hr})\end{array}$ & $\begin{array}{c}\text { Coarse to } \\
\text { moderately fine }\end{array}$ \\
\hline C & $\begin{array}{c}0.05-0.15 \mathrm{in} / \mathrm{hr} \\
(0.13-0.38 \mathrm{~cm} / \mathrm{hr})\end{array}$ & $\begin{array}{c}\text { Moderately fine } \\
\text { to fine }\end{array}$ \\
\hline D & $\begin{array}{c}<0.05 \mathrm{in} / \mathrm{hr} \\
(<0.13 \mathrm{~cm} / \mathrm{hr})\end{array}$ & $\begin{array}{c}\text { Clays with high } \\
\text { swelling, high } \\
\text { water tables }\end{array}$ \\
\hline
\end{tabular}


As described above, the user's decision on the location of LID features is assisted by the terrain analysis tool, which will illustrate the flow and its convergence within the site boundary. The user's decision on the size of LID features is reached by adjusting the area and depth (or volume for cistern) of each feature to achieve the aimed runoff volume of the site. Table 3 lists the constraints of retention capacity of each LID feature adopted in Rainwater+ according to common engineering practice and the manufacturer's catalog. These constraints are included in the Rainwater+ to prevent unrealistic system sizing during the design process. However, users are able to override these settings with custom values if necessary.

Table 3: LID retention capacity constraints

\begin{tabular}{|c|c|}
\hline LID & Constraint \\
\hline Bioretention & $\begin{array}{c}\text { Preferred retention depth between } 6 \\
\text { in and 12 in (max 15 in) }\end{array}$ \\
\hline $\begin{array}{c}\text { Subsurface } \\
\text { infiltration } \\
\text { system }\end{array}$ & $\begin{array}{c}\text { Equivalent retention depth between } \\
1 \mathrm{ft} \text { and } 4.5 \mathrm{ft}\end{array}$ \\
\hline $\begin{array}{c}\text { Permeable } \\
\text { pavement }\end{array}$ & Max retention depth 3 in \\
\hline Green roof & Max retention depth 2 in \\
\hline $\begin{array}{c}\text { Rain harvest } \\
\text { cistern }\end{array}$ & Max retention volume 50,000 gal \\
\hline
\end{tabular}

\section{Case Studies}

\subsection{Site Description}

Two case studies are presented in this study to demonstrate the application of Rainwater+ on real sites and the importance of considering stormwater runoff at the early design stage. Case 1 is a real university campus extension plan, and Case 2 is a new development of a R\&D center. Our goal using these two case studies is to prove the importance and feasibility of integrating rainwater management into the workflow of architects and landscape architects to maximize the site potential of runoff mitigation and rainwater harvesting, which also helps to meet the requirement in corresponding standards and codes such as LEED and state regulations.

The university campus in Case 1 (Figure 3) is located in the Northeastern U.S. with a total area of approximately 178 acres (72 hectares). The development team aims to achieve LEED v4 credits by managing on site the $95^{\text {th }}$ percentile rainfall. Given that the current site consists of a high percentage of previously developed, impervious surfaces, there is an opportunity to reduce the volume of stormwater discharge to the river adjacent to the campus and increase water conservation by rainwater harvesting. 
The site elevations from local government's GIS database show that overall the site is vastly flat, with very sparse contour lines ranging from $9 \mathrm{ft}(2.7 \mathrm{~m})$ to $19 \mathrm{ft}(5.8 \mathrm{~m})$ over several city blocks with no clear surface trend. Therefore we treated the terrain as two-dimensional in our model. The $95^{\text {th }}$ percentile rainfall of 1.52 in $(3.86 \mathrm{~cm})$ was selected from the built-in precipitation library of Rainwater+. Hydrologic soil group $\mathrm{C}$ was also assigned based on site condition.

The project in Case 2 is an R\&D Center also located in the Northeastern U.S. with the site boundary of approximately 64 acres ( 26 hectares) (Figure 5 ). The 1,935 ft $\times 1,440 \mathrm{ft}(590 \mathrm{~m} \times 440$ $\mathrm{m})$ hilly terrain has a large variation in altitude. The greatest difference between the lowest and highest altitude is $164 \mathrm{ft}(50 \mathrm{~m})$. The gross floor area of this development is $538,000 \mathrm{ft}^{2}(50,000$

$\mathrm{m}^{2}$ ), comprised of three major buildings on an elevated platform. One of the project's goals for reaching site sustainability is to manage on site the annual increase in runoff volume from the natural land cover condition to the post-developed condition. The average annual precipitation of the location is approximately 40 inches. On average there are approximately 56 rainfall events with more than 0.1 in in precipitation.

\subsection{Results}

Case 1

Through the preliminary site screening test using Rainwater+, the visualized results as shown in Figure 5 suggest that building roof areas are the most problematic features, followed by the paved roads and walkways. The red and orange colors of these areas illustrate that the largest portion of the 1.52 inches $(3.86 \mathrm{~cm})$ of rainfall falling on these surfaces will run off the site. In contrast, the lawn area in blue shows a partial infiltration capacity. Given the condition that the site is vastly flat, it is assumed that the runoff will be channeled to the designated treatment areas. Therefore, we can skip the Rainwater+ terrain analysis.

In order to better apply localized stormwater management practices, the proposed site has been divided into six sub-zones (Figure 4a) on which the various rainwater management practices are tested with Rainwater+. For cost consideration, we selected bioretention practices first, because these systems generally have the lowest cost per unit of stormwater treated (Dietz, 2007). If bioretention systems are not adequate for capturing the desired runoff volume, permeable pavement, cisterns and green roofs will be considered in the order based on relative costs. In most cases a combination of practices was selected as part of an integrated treatment system. We repeatedly adjusted the system size of these design combinations by trial-and-error and checked the runoff number until it reached zero. The campus plans before and after redesign are shown in Figure 4. 


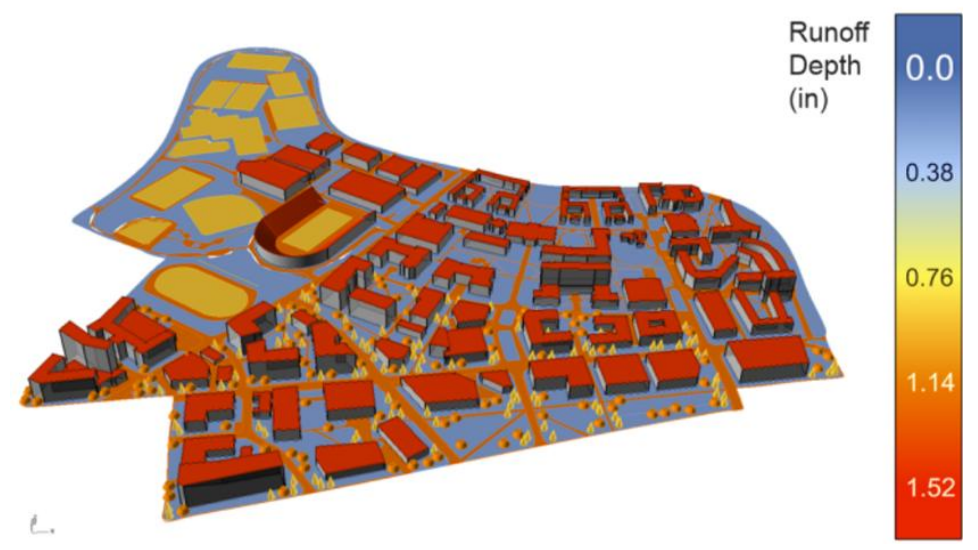

Figure 3: Whole site runoff depth in $95^{\text {th }}$ rainfall event before LID design
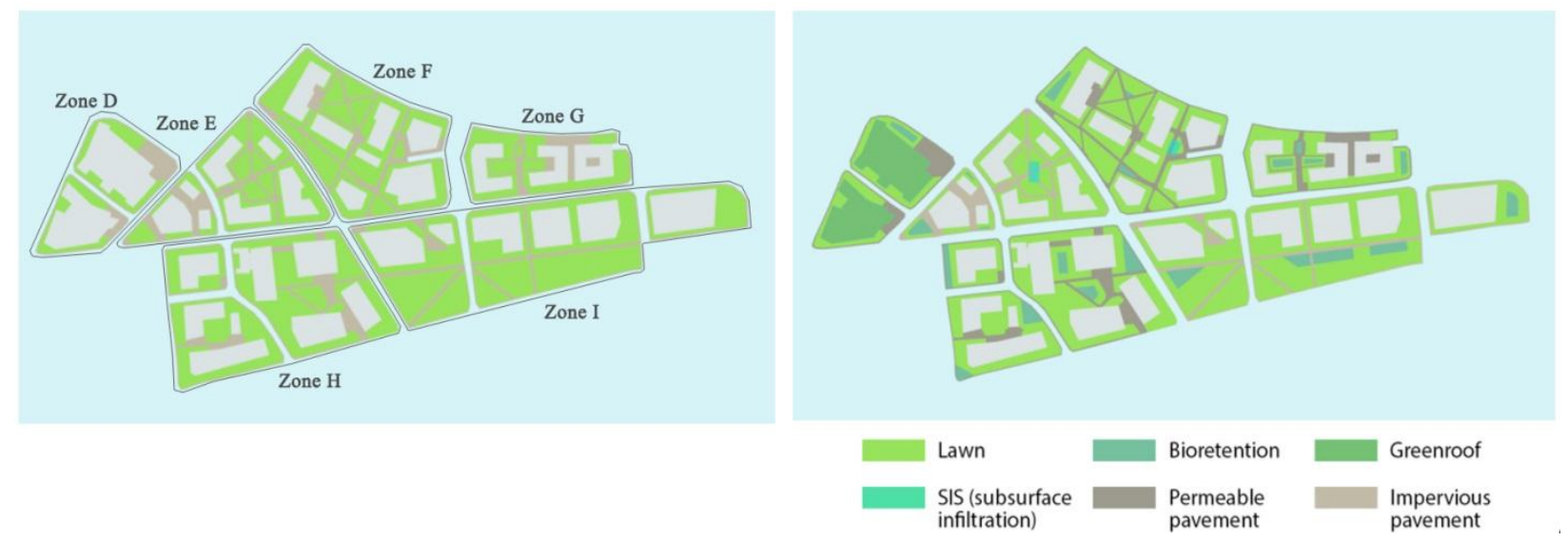

Figure 4 Site plan with and without LID design

The analysis from Rainwater+ suggests that proper LID design is able to offset the total 1.2 million gallons $\left(4,542 \mathrm{~m}^{3}\right)$ of runoff from the entire site in the 95th percentile rainfall event. At the subzone level of each individual land parcel, the combination of bioretention, subsurface infiltration system and porous pavement was sufficient to retain the 95th percentile rainfall on site for a majority of the project zones. Other on-site low-impact stormwater management practices such as rain harvest tanks and green roofs were only needed in one zone with a high Floor Area Ratio (FAR) and percentage of impervious area. 
Table 4: Runoff Calculations - Zone D

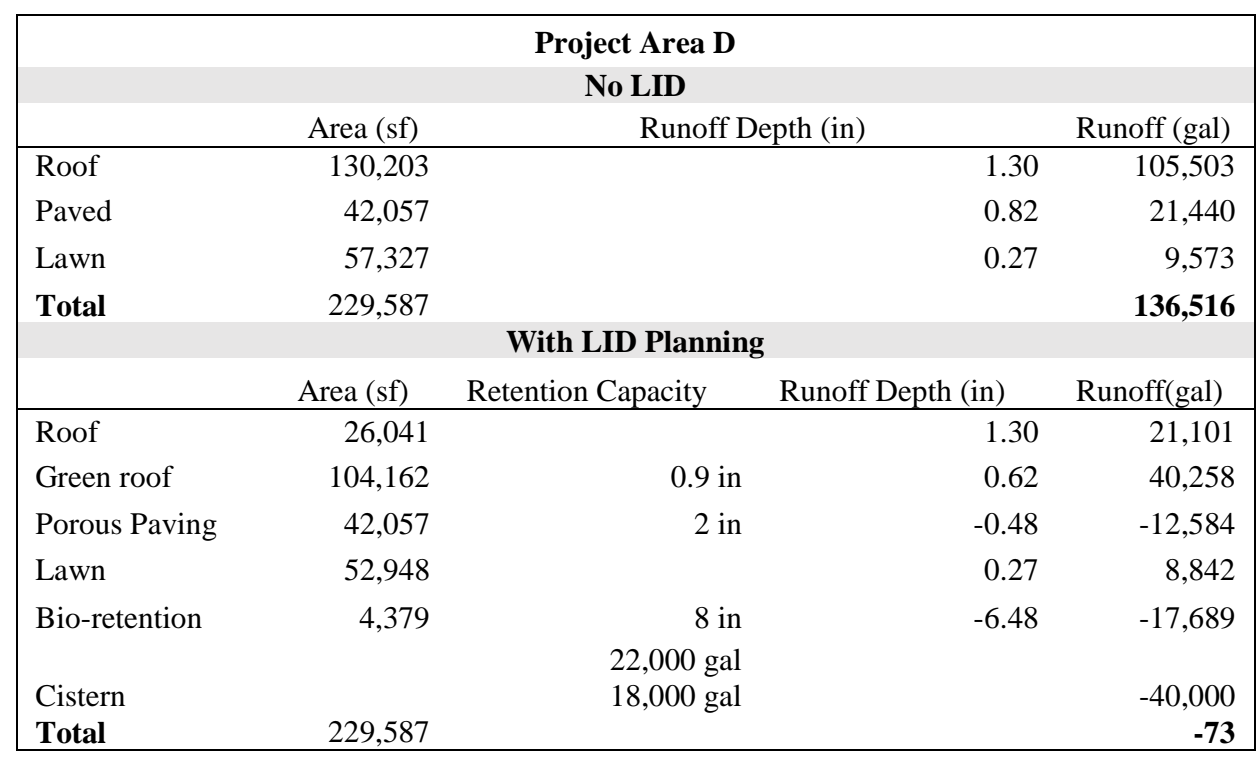

The calculations performed by Rainwater+ for zone D in this case study are shown in Table 4 as an example. 136,516 gal $\left(517 \mathrm{~m}^{3}\right)$ of rainwater will end up as runoff from this $229,587 \mathrm{ft}^{2}$ $\left(21,329 \mathrm{~m}^{2}\right)$ site area in a $95^{\text {th }}$ percentile rainfall event if no mitigation strategy is applied on-site. However, with properly designed 104,162 $\mathrm{ft}^{2}\left(9,677 \mathrm{~m}^{2}\right)$ of green roof with 0.9 in $(2.3 \mathrm{~cm})$ water retention capacity, $42,057 \mathrm{ft}^{2}\left(3,907 \mathrm{~m}^{2}\right)$ of porous paving with 2 in $(5.1 \mathrm{~cm})$ retention capacity, $4,379 \mathrm{ft}^{2}\left(407 \mathrm{~m}^{2}\right)$ of bioretention area with 8 in $(20.3 \mathrm{~cm})$ retention capacity, as well as two rainwater harvest cisterns of $22,000 \mathrm{gal}\left(83 \mathrm{~m}^{3}\right)$ and $18,000 \mathrm{gal}\left(68 \mathrm{~m}^{3}\right)$, theoretically the runoff volume can be entirely offset if the site drainage is appropriately designed.

\section{Case 2}

The aim of this project is to earn LEED v4 credit that requires managing on site the annual increase in runoff volume from the natural land cover condition to the post-developed condition. According to the calculation of Rainwater+, the annual runoff volume of the natural land cover condition without building at this site is $1,311,211 \mathrm{ft}^{3}\left(37,129 \mathrm{~m}^{3}\right)$. In the post-developed condition, the impervious surfaces of building and hard pavement reduce the infiltration capacity of the site and consequently result in an increased runoff volume of 2,099,478 $\mathrm{ft}^{3}\left(59,450 \mathrm{~m}^{3}\right)$, which is equivalent to a $60 \%$ increase. In this project, the selected LID practices are bioretention, permeable pavement and cisterns for rainwater harvest, decisions made after taking cost, site availability and water recycling into consideration. 
a)

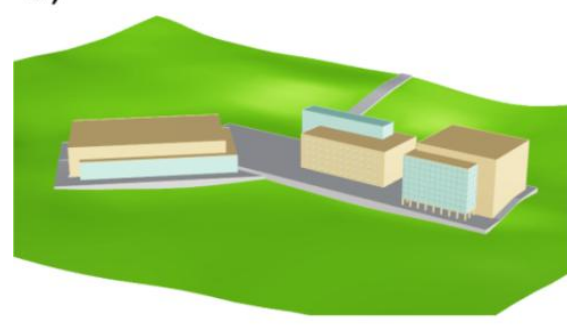

\begin{abstract}
b)
\end{abstract}

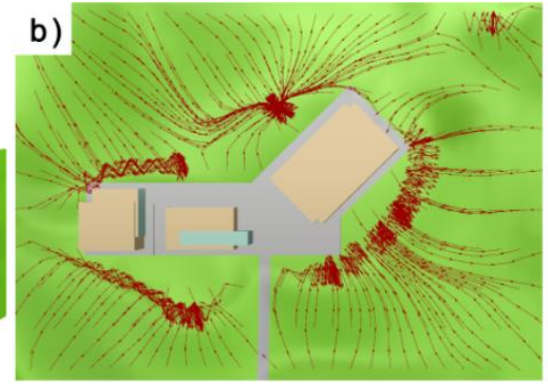

c)

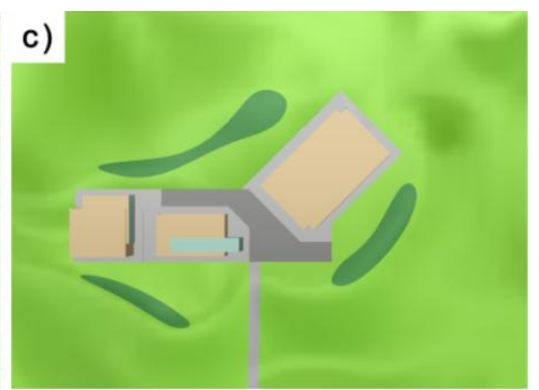

Figure 5: a) Perspective view of the Case 2 design; b) Terrain analysis; c) Design with LID practices

Given the complexity of the terrain at the site, it is critical to consider the runoff flow directions for LID practices. With the aid of the terrain analysis tool in Rainwater+, the flow directions of the runoff are easily visualized. As shown in Figure 5b, the proposed bioretention area can be properly located and sized based on where the rainwater converges in the model. The sum of three bioretention areas are $107,578 \mathrm{ft}^{2}\left(9,994 \mathrm{~m}^{2}\right)$ with retention capacity of 6 in $(15.2 \mathrm{~cm})$. The rainwater harvest cisterns are sized by the corresponding component in Rainwater+, by accounting the runoff volume of each rainfall events within a year from the certain rooftop areas that cisterns are collecting rainwater. Our analysis suggests that two cisterns of 40,000 gal (151 $\left.\mathrm{m}^{3}\right)$ and 20,000 gal $\left(76 \mathrm{~m}^{3}\right)$ are large enough to accommodate $80 \%$ annual rainfall events in order to partially resolve the runoff issue from the rooftop, as well as be an alternative water source for toilet flushing and landscape irrigation. The $60,870 \mathrm{ft}^{2}\left(5,655 \mathrm{~m}^{2}\right)$ pavement of the parking lot is modified to pervious concrete to treat the runoff on-site. The combination of above mentioned LID practices shows a potential capacity to reduce the annual runoff volume of the site to $698,491 \mathrm{ft}^{3}\left(19,779 \mathrm{~m}^{3}\right)$, which is $53.3 \%$ of the natural land cover condition. In addition, theoretically a maximum amount of $219,398 \mathrm{ft}^{3}\left(6,212 \mathrm{~m}^{3}\right)$ of rainwater could be harvested from the rooftop by cisterns. 
Figure 6: Runoff Calculations

\begin{tabular}{c|c|c|c|c|c}
\hline & $\begin{array}{c}\text { Natural land } \\
\text { cover } \\
\text { condition }\end{array}$ & $\begin{array}{c}\text { Design } \\
\text { without LID }\end{array}$ & \multicolumn{2}{|c}{ Design with LID } \\
\hline $\begin{array}{c}\text { Runoff } \\
\left(\mathrm{ft}^{3}\right)\end{array}$ & $\begin{array}{c}\text { Runoff } \\
\left(\mathrm{ft}^{3}\right)\end{array}$ & \multicolumn{1}{|c|}{ LID specification } & $\begin{array}{c}\text { Runoff } \\
\left(\mathrm{ft}^{3}\right)\end{array}$ & $\begin{array}{c}\text { Rainwater } \\
\text { harvest }\left(\mathrm{ft}^{3}\right)\end{array}$ \\
\hline From land & $1,311,211$ & $1,136,336$ & $\begin{array}{l}\text { Three bioretention areas in total of } \\
107,578 \mathrm{ft}^{2}, \text { with retention capacity of } 6 \\
\text { inches }\end{array}$ & 255,342 & \\
\hline From roof & & 458,888 & $\begin{array}{l}\text { Two cisterns of 40,000 and 20,000 } \\
\text { gallon }\end{array}$ & 239,490 & 219,398 \\
\hline From pavement & & 504,254 & $60,870 \mathrm{ft}^{2}$ of porous paving parking lot & 203,769 & \\
\hline Total & $1,311,211$ & $2,099,478$ & & 698,491 & 219,398 \\
\hline
\end{tabular}

\section{Discussion and Conclusion}

A better understanding and assessment of rainwater runoff volume is of great importance for predicting risk and mitigating damage of urban flood, and consequently becomes a crucial issue to be taken into consideration during the early design stage in order to deliver effective result of rainwater management in sustainable development.

The first case study illustrated the importance of integrating rainwater management into computer-aided design (CAD) software, e.g., Rhino, for the reason that visualizing specific site conditions is critical for choosing LID practice. Although there are a few design guidelines, such as cost-effective solutions that can be applied to most projects, the LID design still needs to be considered on a case-by-case base due to the unique site characteristics, such as the shape of building, landscape, and the spatial relationship of them. The second case study demonstrated the important role of terrain analysis tool in the proper placement of LID practice by visualizing runoff flow direction at a site of complex terrain. The capability to size the rainwater harvest cistern also provides designers with great convenience for quick estimation of rainwater collecting potential from the targeted roof area.

Rainwater management is no longer solely the engineer's responsibility in the new era of lowimpact development. In fact, architects and landscape designers may be uniquely positioned to consider rainwater management strategies in early design stage to avoid the lost rainwater management opportunities in the later phase and to prevent construction confliction of building structure and LIDs. However, no tool currently exists to adequately support designers in integrating rainwater performance into their decision-making process.

Considering this context, Rainwater+ is intended to be an intuitive tool for runoff evaluation and management that can enable designers to integrate rainwater considerations into their design workflow with tailored features such as ease of use, instant feedback of runoff volume, seamless 
graphic interconnection, straightforward system sizing, compliance checking, and visualization of rainwater surface flow. The intention of developing Rainwater+ is not to replace the role of the hydrology engineer. Nevertheless, it is designed to encourage early consideration of rainwater management strategies that facilitate more productive interactions with hydrology engineers at the later stage.

\section{Acknowledgement}

We would like to thank Dr. Edward Eric Adams, Professor Joyce Klein Rosenthal, Nicole Holmes and Chelsea Christenson for their insightful comments and suggestions.

\section{References}

Burns MJ, Fletcher TD, Walsh CJ, Ladson AR, Hatt BE. Hydrologic shortcomings of conventional urban stormwater management and opportunities for reform. Landscape and Urban Planning 2012; 105: 230-240.

Carter T, Jackson CR. Vegetated roofs for stormwater management at multiple spatial scales. Landscape and urban planning 2007; 80: 84-94.

Chang N-B. Hydrological connections between low-impact development, watershed best management practices, and sustainable development. Journal of Hydrologic Engineering 2010; 15: 384-385.

Chung W, Wang I, Wang R. Theory-based SCS-CN method and its applications. Journal of Hydrologic Engineering 2010; 15: 1045-1058.

Cronshey R. Urban hydrology for small watersheds. US Dept. of Agriculture, Soil Conservation Service, Engineering Division, 1986.

Cronshey R, Roberts R, Miller N. Urban hydrology for small watersheds (TR-55 Rev.). Hydraulics and Hydrology in the Small Computer Age. ASCE, 1985, pp. 1268-1273.

Dietz ME. Low impact development practices: A review of current research and recommendations for future directions. Water, air, and soil pollution 2007; 186: 351-363.

Dore MH. Climate change and changes in global precipitation patterns: what do we know? Environment international 2005; 31: 1167-1181.

Durrans SR, Dietrich K. Stormwater conveyance modeling and design. 2003.

EPA. Low Impact Development (LID) - A Literature Review. United States Environmental Protection Agency Washington, DC, 2000.

Hsieh C-h, Davis AP. Evaluation and optimization of bioretention media for treatment of urban storm water runoff. Journal of Environmental Engineering 2005; 131: 1521-1531.

Huber WC, Rossman LA, Dickinson R. EPA storm water management model SWMM 5. 0. Watershed Modeling, CRC Press, Boca Raton, FL 2005: 339-361.

Huong H, Pathirana A. Urbanization and climate change impacts on future urban flood risk in Can Tho city, Vietnam. Hydrology and Earth System Sciences Discussions 2011; 8: 10781-10824.

Kim H, Seagren EA, Davis AP. Engineered bioretention for removal of nitrate from stormwater runoff. Water Environment Research 2003: 355-367.

Koo T. Hybrid digital processing in hydrography: the hydrocad solution. Survey Review 1989; 30: 97-108.

Lee JH, Bang KW. Characterization of urban stormwater runoff. Water research 2000; 34: 1773-1780.

Liu Z. Analysis of characteristics and cause of urban storm runoff change and discussion on some issues. Journal of China Hydrology 2009; 29: 55-58.

Mansell MG. Rural and urban hydrology: Thomas Telford, 2003.

Miltner RJ, White D, Yoder C. The biotic integrity of streams in urban and suburbanizing landscapes. Landscape and urban planning 2004; 69: 87-100.

Pyke C, Warren MP, Johnson T, LaGro J, Scharfenberg J, Groth P, et al. Assessment of low impact development for managing stormwater with changing precipitation due to climate change. Landscape and Urban Planning 2011; 103: 166-173.

Qin H-p, Li Z-x, Fu G. The effects of low impact development on urban flooding under different rainfall characteristics. Journal of environmental management 2013; 129: 577-585. 
Samuelson HW, Lantz A, Reinhart CF. Non-technical barriers to energy model sharing and reuse. Building and Environment 2012; 54: 71-76.

Tsihrintzis VA, Hamid R. URBAN STORMWATER QUANTITY/QUALITY MODELING USING THE SCS METHOD AND EMPIRICAL EQUATIONS1. JAWRA Journal of the American Water Resources Association 1997; 33: 163-176.

USDA S. Hydrology, National Engineering Handbook, Section 4. US Department of Agriculture, Washington, DC, USA 1985.

USGBC. LEED v4 User Guide. US Green Building Council, 2013.

Villarreal EL, Semadeni-Davies A, Bengtsson L. Inner city stormwater control using a combination of best management practices. Ecological Engineering 2004; 22: 279-298.

Wang H-z. Calculation Method for Stormwater Infiltration Facilities in Urban Area of Beijing City. CHINA WATER AND WASTEWATER 2001; 17: 37-39.

Whitford V, Ennos AR, Handley JF. "City form and natural process"-indicators for the ecological performance of urban areas and their application to Merseyside, UK. Landscape and urban planning 2001; 57: 91-103. 